\title{
Nanocrystalline silicon oxide interlayer in monolithic perovskite/silicon heterojunction tandem solar cells with total current density $>39 \mathrm{~mA} / \mathrm{cm}^{2}$
}

\author{
Bernd Stannowski ${ }^{1}$, Luana Mazzarella ${ }^{1}$, Yen-Hung Lin ${ }^{2}$, Simon Kirner ${ }^{3}$, Anna B. Morales-Vilches ${ }^{1}$, \\ Lars Korte $^{1}$, Steve Albrecht ${ }^{1}$, Ed Crossland ${ }^{3}$, Chris Case ${ }^{3}$, Henry Snaith ${ }^{2}$, Rutger Schlatmann ${ }^{1}$ \\ ${ }^{1}$ Helmholtz-Zentrum Berlin, Schwarzschildstr. 3, 12489 Berlin, Germany. \\ ${ }^{2}$ Clarendon Laboratory, Oxford University, Parks Road, Oxford OX1 3PU, UK. \\ ${ }^{3}$ Oxford PV, Begbroke Science Park, Woodstock Rd., Oxford OX51PF, UK.
}

\begin{abstract}
Silicon heterojunction solar cells are implemented as bottom cells in monolithic perovskite/silicon tandem solar cells. Commonly they are processed with a smooth front side to facilitate wet processing of the lead-halide perovskite cell on top. The inherent drawback of this design, namely, enhanced reflection of the cell, can be significantly reduced by replacing the amorphous or nanocrystalline silicon front side $n$ layer of the silicon cell by a nanocrystalline silicon oxide $n$ layer. It is deposited with the same commonly used plasma-enhanced chemical vapor deposition and can be tuned to feature opto-electrical properties for enhanced light coupling into the $\mathrm{Si}$ bottom cell, namely, low parasitic absorption and an intermediate refractive index of $\sim 2.6$. We demonstrate that a $80-100 \mathrm{~nm}$ thick layer results in $0.9 \mathrm{~mA} / \mathrm{cm}^{2}$ current gain in the bottom cell yielding tandem cells with a top cell + bottom cell total current above $39 \mathrm{~mA} / \mathrm{cm}^{2}$. These first nc-SiOx:H-coupled tandem cells reach an efficiency $>23.5 \%$.

Index Terms - photovoltaic cells, silicon, heterojunctions, hybrid junctions.
\end{abstract}

\section{INTRODUCTION}

Silicon heterojunction (SHJ) solar cells are attractive for use as bottom cells in monolithic tandem cells with lead-halide perovskite top cells. This is because they have a high efficiency with an open circuit voltage above $730 \mathrm{mV}$ combined with a high spectral response in the NIR regime. Moreover, from a processing point of view the device structure ideally matches the requirements for processing the perovskite top cell, namely, the top layer usually is a tin-doped indium oxide (ITO), which is a good substrate and contact material for the perovskite top cell. Due to the commonly used spin coating process for the perovskite top cell, it has to be deposited on a flat (polished) silicon wafer in order to obtain homogeneous cells without shunts. An early tandem cell reached an efficiency of $19.9 \%$, strongly limited by the bottom cell current [1]. Later a certified stable tandem efficiency of $23.6 \%$ was presented [2] featuring better current matching. This cell, however, was still limited by the short circuit current of $18.1 \mathrm{~mA} / \mathrm{cm}^{2}$ and a total current (top + bottom) below $38 \mathrm{~mA} / \mathrm{cm}^{2}$. The limited total current was due to high reflection losses, partially as result of the flat interfaces.

To overcome the drawback of the flat front side, namely, light reflection out of the tandem cell at the interface between the perovskite $(\mathrm{n} @ 800 \mathrm{~nm}=2.4)$ and the silicon $(\mathrm{n} @ 800 \mathrm{~nm}=$
3.7) sub cell, optical light coupling into the bottom cell by using an intermediate-refractive index material with low parasitic light absorption for wavelengths $>700 \mathrm{~nm}$ is required. One option is plasma-enhanced chemical vapor deposited (PECVD) (doped) nanocrystalline silicon oxide $\left(\mathrm{nc}-\mathrm{SiO}_{\mathrm{x}}: \mathrm{H}\right)$, which has been developed over the past years to replace the doped amorphous silicon contact layers in silicon heterojunction solar cells [3]. Due to its mixed-phase morphology with doped silicon (nano)crystals embedded in an amorphous silicon (sub)oxide matrix [4,5] its optical properties can be tuned over a wide range by varying the oxygen content, without deteriorating the electrical (contact) properties in the cell. We previously showed the superior properties in both-side textured rear p-type emitter SHJ solar cells featuring < $10 \mathrm{~nm}$ thin n-type $n c-\mathrm{SiO}_{\mathrm{x}}: \mathrm{H}$ front contacts, namely, an enhanced short circuit current with excellent electrical properties $\left(\eta=22.6 \%, \mathrm{~J}_{\mathrm{sc}}=\right.$ $38.3 \mathrm{~mA} / \mathrm{cm}^{2}, \mathrm{~V}_{\mathrm{oc}}=731 \mathrm{mV}, \mathrm{FF}=80.6 \%$ ) [6]. Front-side flat cells of the same type and an optically adapted 17-nm thick nc$\mathrm{SiO}_{\mathrm{x}}: \mathrm{H}$ but no $\mathrm{ARC}$ on the front TCO reached an efficiency of $\eta=20.4 \%$, with $\mathrm{j}_{\mathrm{sc}}=35.7 \mathrm{~mA} / \mathrm{cm}^{2}, \mathrm{~V}_{\mathrm{oc}}=719 \mathrm{mV}, \mathrm{FF}=79.6$ $\%$. By adding a PECVD based $\mathrm{SiO}_{2} \mathrm{AR}$ layer on top of the TCO the cell current could be increased by $1.3 \mathrm{~mA} / \mathrm{cm}^{2}$ leading to $21.2 \%$ cell efficiency.

In a recent paper we proposed the use of $n c-\mathrm{SiO}_{\mathrm{x}}: \mathrm{H}$ as an optical interlayer in perovskite / silicon tandem cells [7]. Optical simulations predicted ideal light coupling with $\mathrm{nc}-\mathrm{SiO}_{\mathrm{x}}: \mathrm{H}$ having a refractive index (at $800 \mathrm{~nm}$ ) of 2.6 and a thickness of $90 \mathrm{~nm}$, which would facilitate a current matched tandem cell with $\mathrm{J}_{\mathrm{sc}}=20.1 \mathrm{~mA} / \mathrm{cm}^{2}$, which is a high value for a SHJ cell with flat front interface and only the rear side being textured. Tandem cells with an efficiency up to $30 \%$ are achievable and even higher values appear feasible with improved perovskite bandgap [7]. To validate this predicted high current, we realized tandem cells varying the interlayer refractive index and thickness as given in Table 1. We present the cell results.

\section{EXPERIMENTAL DETAILS}

The tandem device structure realized in the present study is depicted in Figure 1. Rear-emitter silicon heterojunction cells 

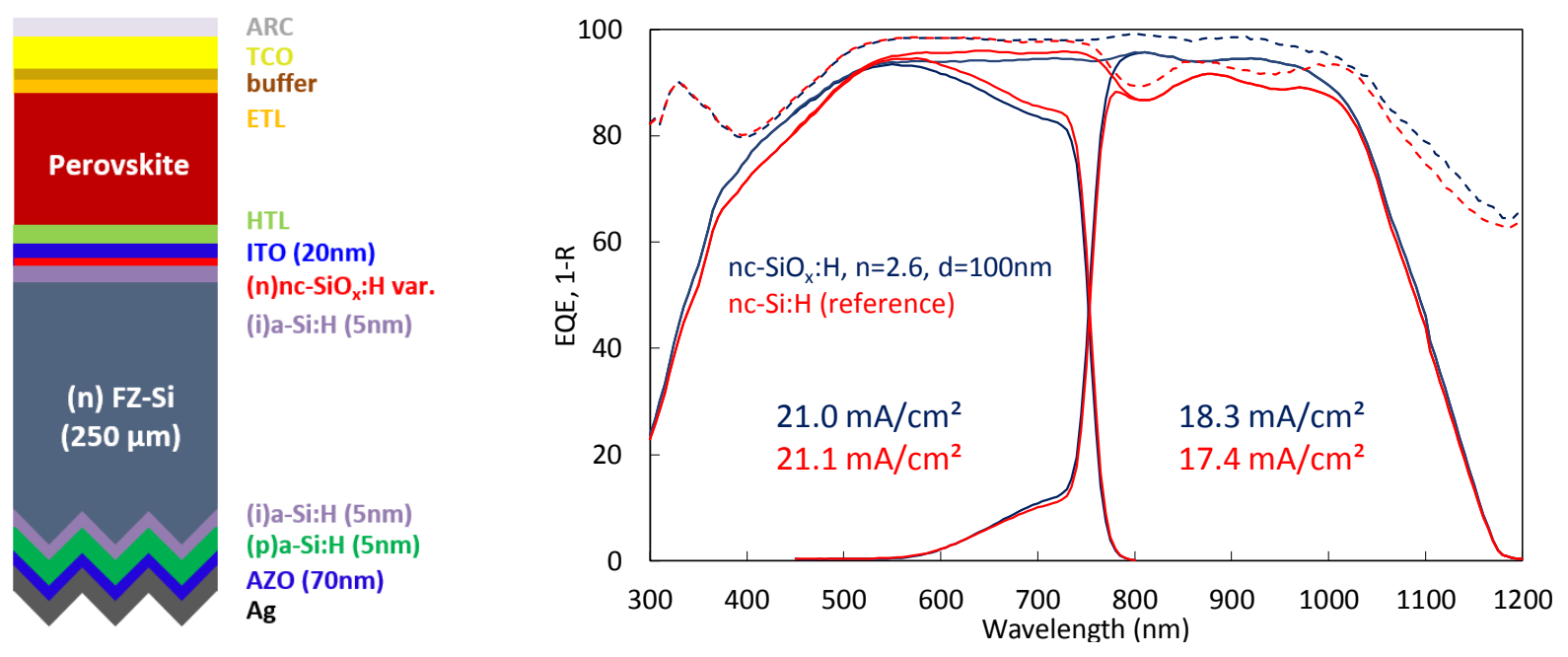

Fig. 1. Left: Schematic cross section of the perovskite/silicon tandem solar cell processed in this study. Right: External quantum efficiency and 1 - total reflection of a tandem cell with nc-SiO $: \mathrm{H}$ interlayer (n @ $800=2.6,100 \mathrm{~nm}$ ) versus the reference cell with nc-Si:H.

were fabricated on $250-\mu \mathrm{m}$ thick float-zone c-Si wafers. Singleside texturing of the rear side by $\mathrm{KOH}$ etching was done with a protecting a-SiO ${ }_{2}$ cap on the polished front side. After cap removal and RCA cleaning of both sides, the silicon layer deposition was carried out in an Applied Materials PECVD cluster tool (AKT1600) applying an amorphous silicon i/p stack on the rear side and an $\mathrm{i} / \mathrm{n}$ stack with (i) amorphous silicon and the (n) $\mathrm{nc}-\mathrm{SiO}_{\mathrm{x}}: \mathrm{H}$ layer as the front contact. By varying the oxygen precursor gas $\left(\mathrm{CO}_{2}\right)$ flow we varied the oxygen content in the film, thereby tuning the refractive index at $800 \mathrm{~nm}$ in the range of 2.2 to 2.9. More details can be found elsewhere [8]. Finally, we sputtered $70 \mathrm{~nm}$ aluminum-doped zinc oxide (ZnO:Al) and $400 \mathrm{~nm} \mathrm{Ag}$ as a rear reflector and contact stack. A 20-nm thick ITO layer was sputtered on the front. Both sputtering steps were done through masks defining $1.1 \mathrm{~cm}^{2}$ cells on both sides of the wafer, with mask openings aligned to each other.

The perovskite top cell junction was fabricated on top of the front ITO cells by spin-coating a p-type poly-TPD doped with F4-TCNQ, followed by deposition of formamidinium, caesium, methylammopnium triple cation perovskite, $\mathrm{FA}_{0.8} \mathrm{Cs}_{0.5} \mathrm{MA}_{0.5} \mathrm{~Pb}\left(\mathrm{I}_{\mathrm{x}} \mathrm{Br}_{1-\mathrm{x}}\right)_{3}$ (where $\mathrm{x} \sim 0.8$ ) using the antisolvent spin-coating method. The perovskite films were cured at $100^{\circ} \mathrm{C}$ for 30 minutes. The devices were completed with $\mathrm{n}$ side contact, window TCO and evaporated gold grid at Oxford PV.

Light IV measurements were performed using a Keithley model 2600 digital source meter and OAI trisol solar simulator. Characteristics were measured using both reverse-forward and forward-reverse bias voltage sweeps, as well as a perturb-andmeasure maximum power tracking algorithm to confirm stabilised power output. External quantum efficiency (EQE) was recorded for each respective subcell using a Bentham PVE300 setup.
For optical simulations $\mathrm{n} \& \mathrm{k}$ parameters of all materials were determined from single layers deposited on glass. The generated current was calculated from the carriers generated in the perovskite and c-Si absorbers, respectively, assuming $100 \%$ carrier collection efficiency.

\section{RESULTS AND DISCUSSION}

We studied SHJ cells with an n-type nc-SiO $: \mathrm{H}$ intermediate layer varying the refractive index (at $800 \mathrm{~nm}$ ) between 2.2 and 2.9 by changing the oxygen content and changing the thickness between 20 and $100 \mathrm{~nm}$. The resulting current densities derived from $\mathrm{EQE}$ are compared to the simulated current densities. For reference a 12-nm thick nc-Si:H n layer (without oxygen), which is the standard $\mathrm{n}$ layer for our SHJ cells, was used. As an example, Figure 1 shows the EQE curve of a tandem cell with an intermediate layer, as compared to the reference. It can be seen that due to suppressed reflection losses in the range of 750 - $1000 \mathrm{~nm}$ the bottom cell gains $0.9 \mathrm{~mA} / \mathrm{cm}^{2}$ at almost constant top cell current.

One of the best cells of this study reached an efficiency of $23.5 \%\left(\mathrm{~V}_{\mathrm{oc}}=1.70 \mathrm{~V}, \mathrm{FF}=76.4 \%\right.$, cf. Fig. 2$)$ even though it is still strongly limited by the bottom-cell current due to the high top cell current and current mismatch. This result shows a clear path to improve the tandem efficiency by minor increase in top cell bandgap (via changes in perovskite composition) that can deliver tandem current matching at $>19.5 \mathrm{~mA} / \mathrm{cm}^{2}$. Table 1 and Figure 3 show experimental and simulated results demonstrating the trend as was generally predicted from simulations [7]. An optimum nc- $\mathrm{SiO}_{\mathrm{x}}: \mathrm{H}$ refractive index of 2.6 -2.9 is found. With increasing thickness the bottom cell current is raised, saturating around $80-100 \mathrm{~nm}$ thickness. This trend is driven by the reduced reflection out of the cell, due to better light coupling into the bottom cell. The gain is on the order of $1 \mathrm{~mA} / \mathrm{cm}^{2}$ in the experiments and slightly higher in the 
simulations. The top cell current is unaffected. A total current density (top cell + bottom cell) as high as $39.3 \mathrm{~mA} / \mathrm{cm}^{2}$ is obtained for the optimized configuration.

\section{CONCLUSIONS AND OUTLOOK}

We demonstrated by means of experiments and simulations that the incorporation of an optimized n-type nc-SiO $\mathrm{x}: \mathrm{H}$ interlayer in perovskite/silicon heterojunction tandem cells between the top and bottom cell leads to an increase of the bottom-cell current density by $1 \mathrm{~mA} / \mathrm{cm}^{2}$. With the best cells shown here having $23.5 \%$ efficiency and further adjustment to match both cells' currents a rapid further improvement to reach a device efficiency to $>25 \%$ by using a wider band gap perovskite seems very feasible.

\section{ACKNOWLEDGEMENTS}

The authors gratefully acknowledge the financial support by the German Federal Ministry of Economic Affairs and Energy (BMWi) within the "PersiST" project (No. 0324037C). S.A. acknowledges the Federal Ministry of Education and Research (BMBF) for funding of the Young Investigator Group (grant no.03SF0540) within the project "Materialforschung für die Energiewende".

\section{REFERENCES}

[1] S. Albrecht, M. Saliba, J. Correa Baena, F. Lang, L. Kegelmann, M. Mews, L. Steier, A. Abate, J. Rappich, L. Korte, R. Schlatmann, M. Nazeeruddin, A. Hagfeldt, M. Grätzel and B. Rech, "Monolithic perovskite/silicon-heterojunction tandem solar cells processed at low temperature", Energy \& Environmental Science, vol. 9, pp. 81-88, 2016.

[2] K. Bush, A. Palmstrom, Z. Yu, M. Boccard, R. Cheacharoen, J. Mailoa, D. McMeekin, R. Hoye, C. Bailie, T. Leijtens, I. Peters, M. Minichetti, N. Rolston, R. Prasanna, S. Sofia, D. Harwood, W. Ma, F. Moghadam, H. Snaith, T. Buonassisi, Z. Holman, S. Bent and M. McGehee, "23.6\%-efficient monolithic perovskite/silicon tandem solar cells with improved stability", Nature Energy, vol. 2, p. 17009, 2017.

[3] L. Mazzarella, A. Morales-Vilches, M. Hendrichs, S. Kirner, L. Korte, R. Schlatmann and B. Stannowski,"Nanocrystalline n-Type Silicon Oxide Front Contacts for Silicon Heterojunction Solar Cells: Photocurrent Enhancement on Planar and Textured Substrates", IEEE Journal of Photovoltaics, vol. 8, pp. 70-78, 2017.

[4] P. Cuony, M. Marending, D. T. L. Alexander, M. Boccard, G. Bugnon, M. Despeisse, and C. Ballif, Appl. Phy. Lett., vol. 97, p. 213502, 2010.

[5] M. Klingsporn, S. Kirner, C. Villringer, D. Abou-Ras, I. Costina, M. Lehmann and B. Stannowski, "Resolving the nanostructure of plasma-enhanced chemical vapor deposited nanocrystalline SiOx layers for application in solar cells", Journal of Applied Physics, vol. 119, p. 223104, 2016.

[6] L. Mazzarella, A. B. Morales-Vilches, L. Korte, R. Schlatmann and B. Stannowski, "Ultra-thin nanocrystalline n-type silicon oxide front contact layers for rear-emitter silicon heterojunction solar cells", Sol. Energy Mater. Sol. Cells, vol. 179, pp. 386-391 2018.

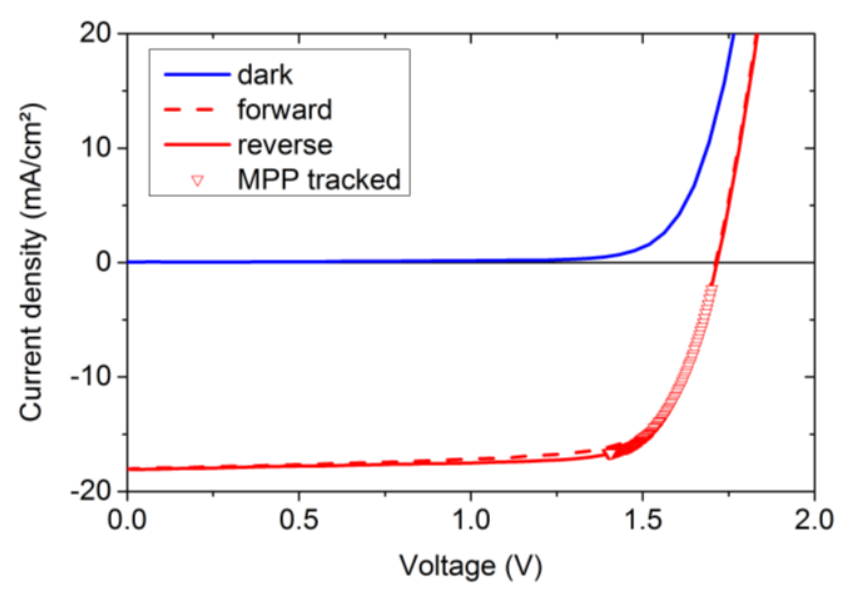

Fig. 2. Light IV curve of a $23.5 \%$ perovskite/SHJ tandem cell with a $80-\mathrm{nm}$ thick nc-SiO $: \mathrm{H}$ interlayer with $\mathrm{n}_{\text {nc-SiOx: }} \mathrm{H}(800 \mathrm{~nm})=2.6$.

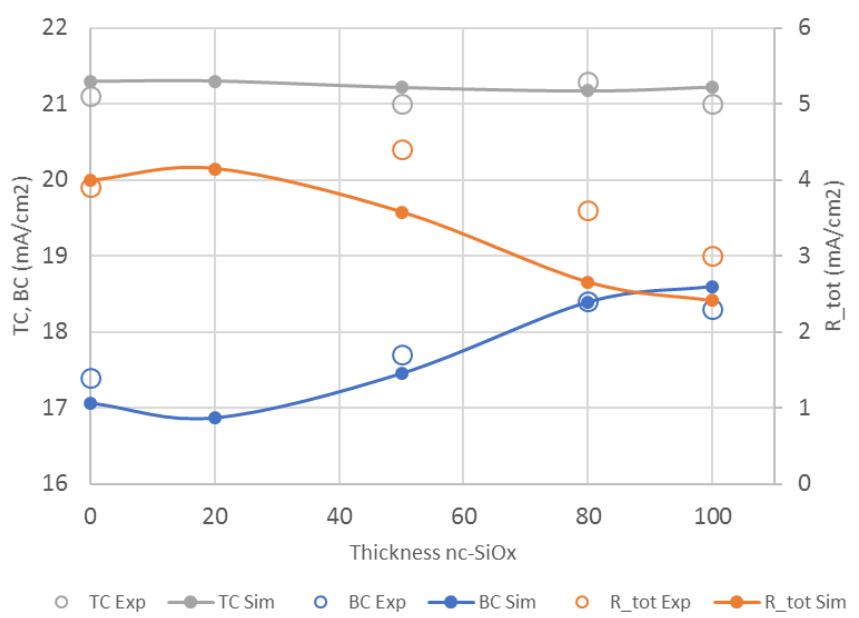

Fig. 3. Experimental and simulated current density for top and bottom

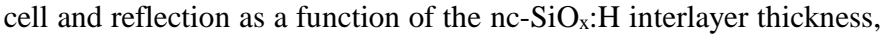
for $\mathrm{n}_{\text {nc-SiOx }}(800 \mathrm{~nm})=2.6$.

TABLE I

PHOTO CURRENTS DETERMINED FROM EQE AND REFLECTION MEASUREMENTS AND EQUIVALENT PHOTO CURRENTS FROM OPTICAL SIMULATIONS, ASSUMING 100\% CARRIER COLLECTION EFFICIENCY FOR CHARGES GENERATED IN THE PEROVSKITE AND SILICON ABSORBER LAYERS.

\begin{tabular}{|c|c|c|c|c|c|c|c|}
\hline \multicolumn{2}{|c|}{ nc-SiO $: H$} & \multicolumn{2}{|c|}{ Top cell } & \multicolumn{2}{|c|}{ Bottom cell } & \multicolumn{2}{|c|}{ R_tot } \\
\hline Thickn. & $\mathrm{n}$ & Exp. & Sim. & Exp. & Sim. & Exp. & Sim. \\
\hline $\mathrm{nm}$ & - & \multicolumn{6}{|c|}{ Integrated values $(300-1200 \mathrm{~nm})$ in $\mathrm{mA} / \mathrm{cm}^{2}$} \\
\hline 0 & - & 21.1 & 21.3 & 17.4 & 17.1 & 3.9 & 4.0 \\
\hline 20 & 2.6 & - & 21.3 & - & 16.9 & - & 4.1 \\
\hline 50 & 2.6 & 21.0 & 21.2 & 17.7 & 17.5 & 4.4 & 3.6 \\
\hline 80 & 2.6 & 21.3 & 21.2 & 18.4 & 18.4 & 3.6 & 2.7 \\
\hline 100 & 2.6 & 21.0 & 21.2 & 18.3 & 18.6 & 3.0 & 2.4 \\
\hline 50 & 2.9 & 21.0 & 21.2 & 17.9 & 17.7 & 3.8 & 3.4 \\
\hline 50 & 2.2 & 21.1 & 21.3 & 16.6 & 16.7 & 5.2 & 4.3 \\
\hline
\end{tabular}


[7] L. Mazzarella, M. Werth, K. Jäger, M. Jost, L. Korte, S. Albrecht, R. Schlatmann, B. Stannowski, "Infrared photocurrent management in monolithic perovskite/silicon heterojunction tandem solar cells by using a nanocrystalline silicon oxide interlayer", Opt. Express, vol. 26, pp. 81-88, 2018.
[8] O. Gabriel, S. Kirner, M. Klingsporn, F. Friedrich, B. Stannowski, R. Schlatmann, "On the plasma chemistry during plasma enhanced chemical vapor deposition of microcrystalline silicon oxides", Plasma Process. Polym., vol. 12, pp. 82-91, 2015. 